\title{
18. SUMMARY OF DRILLING RESULTS FOR THE MISSISSIPPI FAN AND CONSIDERATIONS FOR APPLICATION TO OTHER TURBIDITE SYSTEMS 1
}

\author{
William R. Normark, Audrey W. Meyer, Michel Cremer, Laurence Droz, Suzanne O'Connell, Kevin T. Pickering, \\ Charles E. Stelting, Dorrik A. V. Stow, Gregg R. Brooks, James Mazzullo, Harry Roberts, and Paul Thayer ${ }^{2}$
}

\begin{abstract}
This chapter summarizes the results of Leg 96 sedimentologic studies of the Mississippi Fan. These studies principally describe the youngest fan lobe (deposited during late Wisconsin time) and indicate that a substantial amount of sand was transported through a leveed channel system to the lower fan during that period. Significant amounts of coarsegrained material were also left as a channel lag in the middle fan region. Recovery of these sands was poor, however, and a direct correlation of the Mississippi Fan sections with classic Mutti-Ricci Lucchi facies could not be made. Major submarine slide and debris-flow deposits suggest that a significant portion of the total sediment contribution to the fan might come from the margins of the Gulf of Mexico and not necessarily follow the existing channel system. Good recovery of fine-grained sediment in the upper 50 to $100 \mathrm{~m}$ at most sites provides substantial insight on depositional processes of muddy turbidity currents and other density flows in a passive margin, large-scale submarine fan setting. In general, the drilling results on the Mississippi Fan are compatible with seismic stratigraphic interpretations.
\end{abstract}

\section{INTRODUCTION}

For ease of discussion, most authors of chapters in this volume have keyed their analyses to geomorphic or sedimentologic characteristics of the fan. These characteristics include fan divisions (upper, middle, lower), channel features (meanders, thalwegs, and levees), and depositional settings (slumps, slides, channel fills, overbank areas, and channel-termination lobes). However, these descriptive characteristics and other terms used to describe turbidite systems to date have not been consistently used for either modern or ancient deposits (Barnes and Normark, 1985; Bouma, Normark, and Barnes, 1985). As a result, these terms are not well defined, even for the Mississippi Fan.

Although Leg 96 provided the first extensive deep sampling of a modern submarine fan, there is considerable potential for confusion if too much is read into our results, especially given the lack of standardized fan terminology and the great variety of fan systems. Specifically, our drilling results did not allow an adequate assessment of sedimentologic facies on this modern fan to resolve the problems of comparing modern deposits to facies models for ancient turbidites. The purpose of this chapter is, therefore, to review the sedimentologic results of drilling on the Mississippi Fan, while suggesting some limitations on the interpretation of these results

\footnotetext{
${ }^{1}$ Bouma, A. H., Coleman, J. M., Meyer, A. W., et al., Init. Repts. DSDP, 96: Washing. ton (U.S. Govt. Printing Office).

2 Addresses: (Normark) U.S. Geological Survey, 345 Middlefield Road, Menlo Park, CA 94025; (Meyer, O'Connell) Ocean Drilling Program, Texas A\&M University, College Station, TX 77843; (Cremer) Laboratoire de Géologie et Océanographie, Université de Bordeaux I, Avenue des Facultes, 33405 Talence, France; (Droz) Laboratoire de Géodynamique Sous-Marine, Université Pierre et Marie Curie, Villefranche-sur-Mer, France; (Pickering) Department of Geology, University of Leicester, Leicester LEI 7RH, United Kingdom; (Stelting) Chevron Oil Field Research Co., Houston, TX 77236; (Stow) Geology Department, Nottingham Uni-

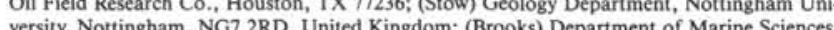
University of South Florida/St. Petersburg. St. Petersburg, FL 88701; (Mazzullo) Department of Geology, Texas A\&M University, College Station, TX 77843; (Roberts) Coastal Studies Institute, Louisiana State University, Baton Rouge, LA 70803; (Thayer) Mobil Oil Exploration and Producing Southeast, Ine., 1250 Poydras Bldg., New Orleans, LA 70113.
}

for modifying or erecting fan sedimentation "models." In general, we attempt to apply the working concepts derived from the recent COMFAN book (Barnes and Normark, 1985; Normark et al., 1985).

\section{BACKGROUND}

\section{Drilling Objectives}

Major objectives for drilling the Mississippi Fan during Leg 96 were (1) to establish a time-stratigraphic framework by determining the lithologic nature of the sediment and the age of prominent seismic reflectors; (2) to develop a sediment distribution model for the youngest fan lobe; (3) to determine if the sinuous middle-fan channel is migratory in nature; (4) to establish the lithologic characteristics of the middle-fan channel fill, especially of the high-amplitude acoustic zone present in the deeper part of that fill; (5) to evaluate the importance of sand transport to the lower fan and its mode of deposition; (6) to supplement existing data on facies from passive continental margin settings for comparative purposes; and (7) to determine the physical and chemical characteristics of the fan deposits (for a more detailed list, see Introduction, Objectives, and Principal Results chapter, this volume). In addition to providing sediment facies information, drilling results would supply a tie between sedimentary facies and $3.5-\mathrm{kHz}$ and medium-resolution acoustic facies, by providing for the first time sediment cores below the upper $10 \mathrm{~m}$, a practical depth limit for existing piston core samples from modern fans. Although these objectives include a variety of sedimentologic aspects, the drilling program endorsed by the JOIDES Planning Committee placed a high priority on reaching specific seismic reflectors, including Horizons " 20 " and " 30 " (Stelting et al., this volume), to ascertain sediment accumulation rates and the lithologic character of these fanwide reflectors.

It is arguable whether the Mississippi Fan was a suitable choice for drilling if the objectives had been solely 
sedimentologic. The choice of this submarine fan for the major drilling program was a realistic compromise that considered ship schedule, background data available at the time, expected technical difficulties, stratigraphic and sedimentologic objectives, safety considerations, and many other factors. However, the basic data that have been used to construct facies associations for turbidite sequences have come from detailed section measurements of ancient turbidite systems deposited on continental crust in tectonically active basins generally much smaller than the Gulf of Mexico basin (Barnes and Normark, 1985). In many cases, the grain size and rate of sediment supply to these ancient turbidite systems reflect the active tectonic setting and restricted basin area (Stow et al., 1985), and the fan systems that develop show appreciable differences from large fans growing in deep water on passive continental margins. Thus, it is not surprising that the recovered cores from the Mississippi Fan do not provide a strong tie to ancient facies associations now used to construct a plethora of fan models. Our comments do not imply that Leg 96 failed to collect valuable new sedimentologic data for passivemargin submarine fans, but only that our results can not provide the much-needed facies associations from a modern environment that are the equivalent of those now in hand for ancient sequences.

\section{Previous Studies and Related Research}

The Mississippi Fan provided a prime target for Leg 96 drilling, in part because of the large amount of information about the adjacent shelf and delta regions available from extensive offshore drilling and geophysical surveys. It was felt that drilling results from this fan could be used to interpret growth patterns of other large passive-margin deep-sea fans. General summaries of the geologic framework of the northern margin of the Gulf of Mexico are given by Martin (1978), Moore et al. (1979), and Addy and Buffler (1984). Although much of the data comes from industry, and hence is proprietary, the Introduction, Objectives, and Principal Results chapter (this volume) summarizes the major implications of available data for deducing the depositional history of the fan. In addition, the general structure and stratigraphy of the deep Gulf of Mexico basin are relatively well known (Moore et al., 1979; Shaub et al., 1984), and are supplemented by results from DSDP Legs 1, 10, and 77 (Ewing, Worzel, et al., 1969; Worzel, Bryant, et al., 1973; Schlager, Buffler, et al., 1984).

From these geophysical surveys and industry borings, the general growth sequence of the fan, determined through seismic stratigraphic analysis, can be tied to the history of basin filling, the structure of the margin, and the source of sediments, including some information about the timing and rate of supply. The growth sequence is defined by a series of at least seven discrete depositional units termed fan lobes. A fan lobe is defined as a body of submarine fan deposits that accumulated during a relatively short geologic interval and is separated from underlying and adjacent fan lobes by a seismic reflector that can be correlated across the extent of that fan lobe (Bouma, Stelting, et al., 1985). Fan lobes on the Mississippi Fan are further subdivided into four major regions: an erosional canyon incised into the shelf and upper slope; an upper fan with a large, nearly filled, erosional channel; an aggradational middle fan which is convex in cross section and has a central, sinuous leveed channel; and, an aggradational lower fan with multiple, smaller channels, only one of which appears active at any specific period of geologic time (Introduction, Objectives, and Principal Results, this volume; Fig. 1).

The discrete depositional packets that form the main body of the Mississippi Fan are similar to growth patterns interpreted for the Rhone Fan (Droz and Bellaiche, 1985). In both cases, the depositional packets are elongate lenticular units that are clearly tied to the growth of a leveed-valley sequence. Similar, but larger and seemingly more complicated, depositional packets have also been mapped on the Bengal (Curray et al., 1982) and Amazon (Damuth et al., 1983) fans. All four of these fans have formed on oceanic crust off major river deltas, so the drilling results from the Mississippi Fan might have general application to fans with similar seismic stratigraphic signatures and regional settings.

The general morphology of the Mississippi Fan is known (Stuart and Caughey, 1976; Moore et al., 1978, 1979; Bouma, Coleman, et al., 1985), but detailed bathymetric maps and comprehensive studies of the channel patterns based on 1985 GLORIA surveys are being completed at the time of this writing. The limited GLORIA side-scan survey and subsequent site surveys prior to Leg 96 followed only a southeastward-trending channel that was thought to be the main distributary system east of $88^{\circ} \mathrm{W}$ longitude (Garrison et al., 1982, fig. 1; Kastens

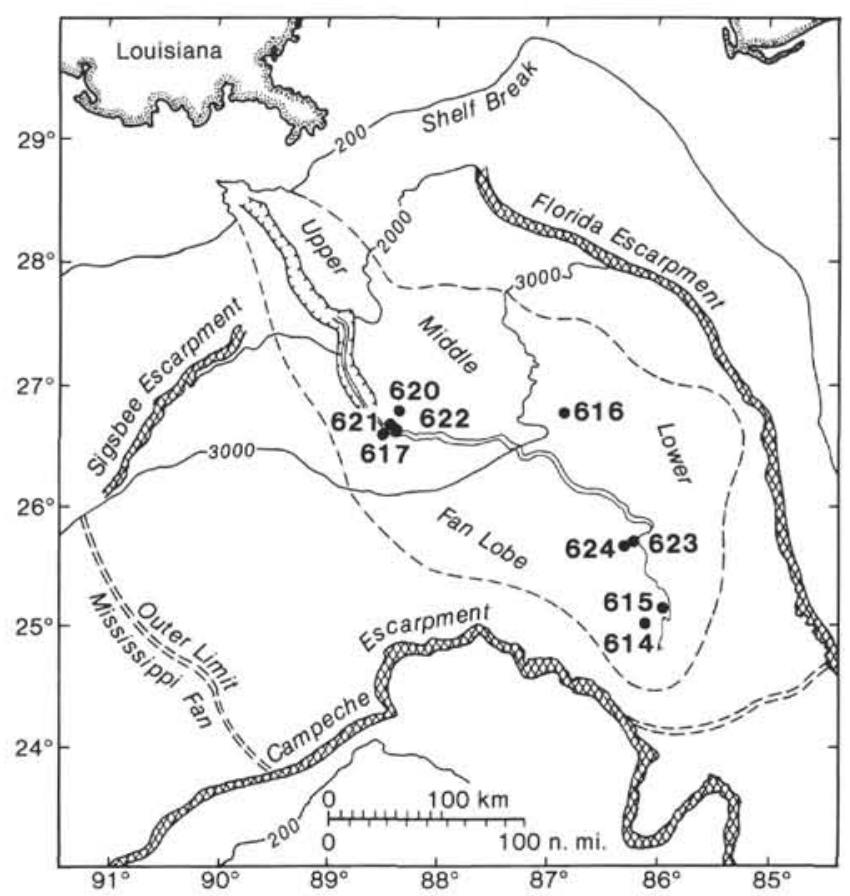

Figure 1. Location map of sites drilled on the Mississippi Fan during DSDP Leg 96. Upper, middle, and lower fan morphologic regions, as recognized by the shipboard scientific party, are shown. Bathymetric contours in meters. 
and Shor, 1985; O'Connell, 1986). Further analyses of these data after the cruise, however, show a complicated pattern of channels and channel remnants whose histories can not be related to the depositional sequence within the youngest fan lobe and are not clearly related to drill sites (O'Connell, 1986; Fig. 2). The discontinuous channel system in the area of the lower fan sites has been confirmed by the most recent GLORIA mapping (B. MacGregor, pers. comm., 1985). The complications in sediment dispersal pathways indicated by these high-resolution reflection profiles and side-scan sonar data cannot be adequately interpreted without more extensive sediment samples from the fan surface for the sites south of $26^{\circ} \mathrm{N}$ latitude, where the channel sequences cannot be adequately resolved in reflection profiles.

Thus, sedimentary facies distinctions of the cored material from Leg 96 can fit several interpretations of the depositional environment on the fan, based on the evolving picture of local channel history and lobe deposition (compare Figs. 1 and 3). This uncertainty is especially evident below the upper $100 \mathrm{~m}$ at all sites (Fig. 4), where coarser grained sediment resulted in incomplete recovery, making interpretations of sediment sequences particularly tenuous.

We note here that a problem will be encountered when attempting to extend the Mississippi Fan drilling results to other modern fans, in that the distinction of upper, middle, and lower fan divisions adopted by the Leg 96 scientific staff (and used throughout this volume) differs from the convention that the senior author defined in an active-margin fan setting and that has been used by many authors during the past $15 \mathrm{yr}$. (Normark, 1978). The fan divisions adopted by the Leg 96 scientific staff are based on the morphologic characteristics, seismic facies distribution, and seafloor gradient of the Mississippi Fan (Fig. 1; Stelting et al., this volume), which may be representative only of large, passive-margin fan deposits that differ in tectonic setting and sediment source from active-margin fans. These differences do not imply that there is a wrong or right method to define fan subdivisions, but that several approaches can be used. Figure 3 shows another possible interpretation for the Mississippi Fan, and the reader is referred also to other differences between fans in the comparisons by Barnes and Normark (1985). If we had instead chosen fan divisions based on the morphology and channel characteristics defined for submarine fans in active-margin settings, then all sites drilled on Leg 96 would be on the upper fan except for Sites $614,615,623$, and 624 , which would fall in the middle fan (Fig. 3). As pointed out by Normark et al. (1985), use of morphologic divisions of fans can lead to misleading comparisons and should perhaps be avoided in applying the Leg 96 results to other fans that are not formed in deep water and fed by large rivers.

\section{RESULTS}

A total of nine sites were occupied on the Mississippi Fan during Leg 96, four on the middle fan (Sites 621 and 622 in the channel; Sites 617 and 620 in the overbank region), four on the lower fan (Sites 623 and 624 on the upper part of the lower fan in the channel switch- ing region; Sites 614 and 615 on the lower part of the lower fan where the channels terminate), and one (Site 616) on the flank of the youngest fan lobe and within a surficial slide deposit (see site chapters, this volume). Most of the holes drilled at these sites penetrated only the youngest fan lobe, which overlies seismic Horizon " 20 " (Introduction, Objectives, and Principal Results, this volume) and was deposited during late Wisconsin time (Ericson Zone Y of Ericson and Wollin, 1968; see Kohl et al., this volume, for oxygen-isotope stage correlations). Core descriptions and well-log data from these sites are summarized in Figure 4; schematic lithologic sections from the uppermost $100 \mathrm{~m}$ at each site, where recovery was best, are shown in Figure 5.

Generally speaking, drilling results show that sand and gravel are concentrated in the middle-fan channel fills and in the lower-fan channel fills and depositional lobe area. Silt and clay are concentrated in overbank deposits and uppermost channel fills, and are interbedded with coarser grained sediments on the lower fan.

In this section, we first describe the results of Leg 96 geophysical, sedimentologic, and well-log studies. We then present a summary of Mississippi Fan lithologic facies and depositional environments, as determined from the results of these studies.

\section{Geophysical Studies}

The internal structure and seismic character of the youngest fan lobe are described by Stelting et al. (this volume), using medium- and high-resolution seismic data (air gun and water gun), supplemented by $3.5-\mathrm{kHz}$ and side-scan sonar data. These data form the basis for division of the fan lobe into the four morphologic regions described above (see table 2 in Stelting et al., this volume). Drill data provide direct biostratigraphic and lithologic control for the middle and lower fan regions; no sites were drilled in either the upper fan or canyon regions during Leg 96.

The late Wisconsin section of the middle fan lobe is composed of three primary seismic types: (1) thick, virtually structureless, transparent zones with scattered reflections; (2) parallel reflectors, divisible by degree of lateral continuity into three separate facies-continuous, discontinuous, and irregular discontinuous; and (3) highamplitude, low-continuity reflectors (Stelting et al., this volume). The first two types characterize the overbank areas. The thick transparent zones coincide with the "slump" area reported by Walker and Massingill (1970) using $3.5-\mathrm{kHz}$ data; this area is believed to consist of numerous, imbricated, small mass-movement deposits. Outside the "slump" area, overbank deposits are characterized by parallel reflectors intermixed with transparent to semitransparent patches (see fig. 8 in Stelting et al., this volume). Generally, the distribution of the three parallel-reflector facies indicates that the lateral continuity increases away from the channel complex and downfan; overbank spilling of density currents and local mass movements are the inferred depositional processes. The third primary seismic type-high-amplitude reflectorsis observed only in the deeper part of the channel fill, but occurs throughout the length of the middle-fan chan- 


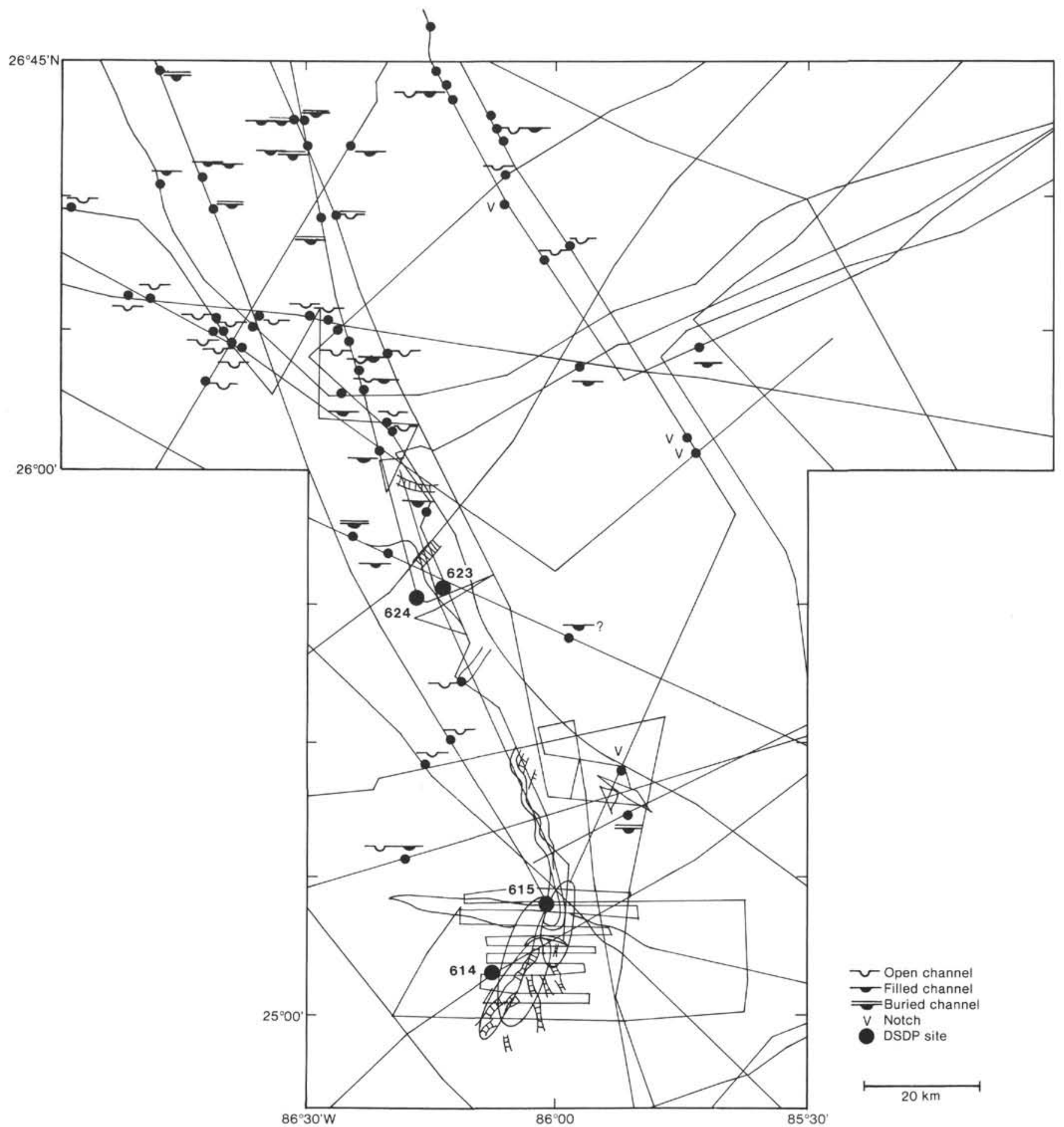

Figure 2. Annotated shiptracks for cruises where seismic reflection and/or side-scan sonar data were collected downslope from the main leveed channel (modified from O'Connell, 1986). Where observed by side-scan sonar, the actual channel shape is shown with two parallel lines; space between parallel lines is blank for open channels and hachured for filled channels. Otherwise, channel crossings are indicated by small dots, and the degree of channel fill is shown by a symbol. Open channels occur where there is a clearly marked depression that can be connected between tracklines. Levee-like structures may be present. Filled channels are depressions that have been filled; the fill is identified because it has a different acoustic response. A slight depression may still be present on the surface, although filled channels do not necessarily have bathymetric relief. Buried channels do not have a surface expression. They are recognized on seismic reflection profiles by a narrow band of high-amplitude reflectors in the subsurface. Notches are slight depressions in the seafloor that cannot be traced to depressions on other nearby reflection profiles. 


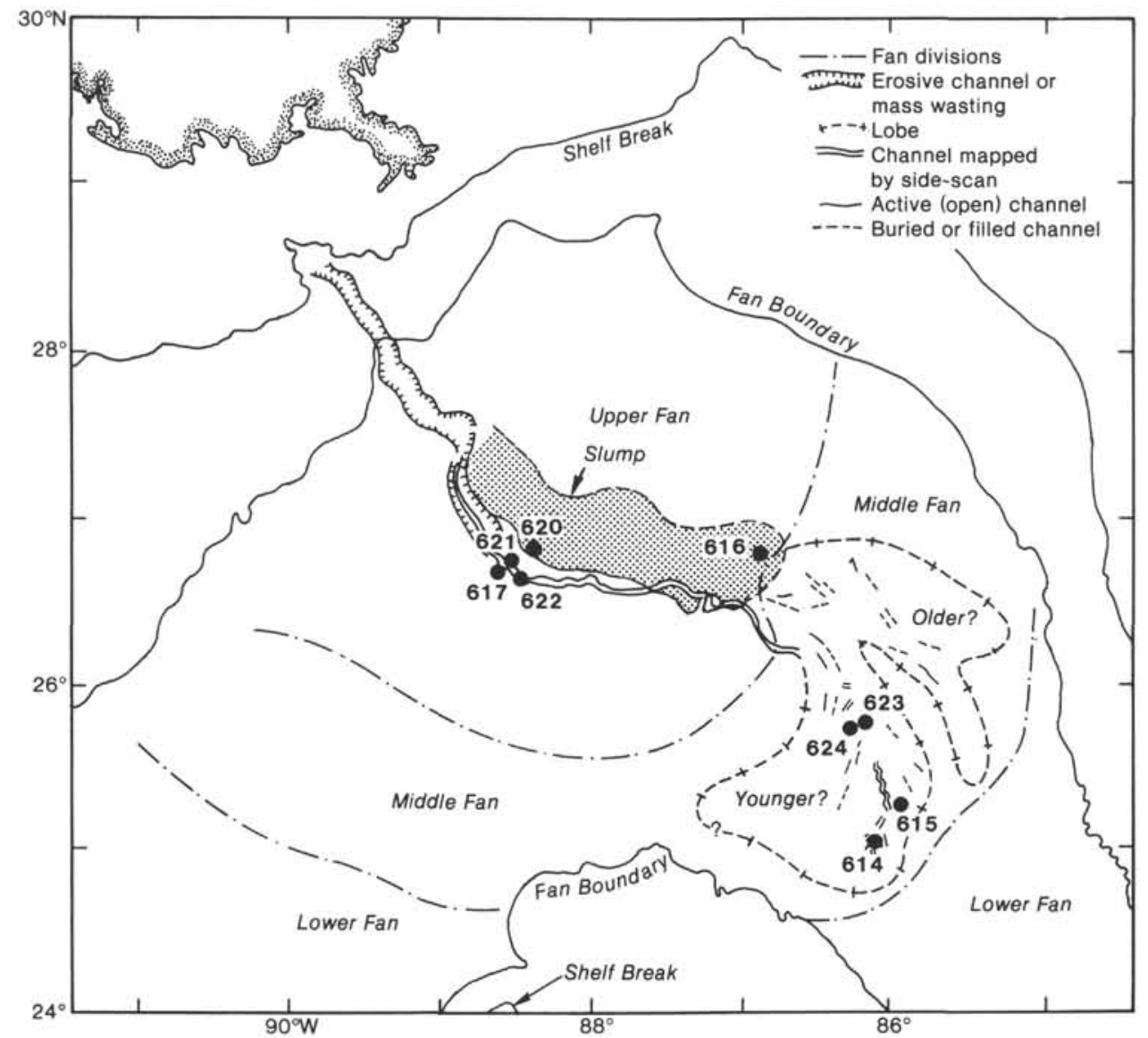

Figure 3. Schematic interpretation of Mississippi Fan morphology combining Figure 2 in Bouma, Stelting, et al. (1985) and Figure 2 in this chapter. Except for channels observed by side-scan sonar, actual trends are unknown. Fan divisions are based on Normark's (1978) model for active-margin fans and provide alternate interpretations (see text).

nel (see fig. 9 in Stelting et al., this volume). Correlation of this seismic facies with coarse-grained sediment recovered from Sites 621 and 622 (see site chapters, this volume) suggests that this facies corresponds to channel-lag deposits. The configuration of the high-amplitude reflectors indicates that the middle-fan channel has migrated laterally and aggraded upward through time (Kastens and Shor, 1985; Stelting et al., 1985).

Seismic profiles across the lower fan basically show a dominance of parallel reflectors, although the character of the seismic facies varies according to the nature of the channel system (Stelting et al., this volume). Seismic profiles across the upper portion of the lower fan (near Sites 623 and 624) show lobate, discontinuous parallel reflectors and numerous small cut-and-fill features resulting from the deposition of small sand lobes as the channels in this region frequently switched position (see fig. 10 in Stelting et al., this volume). Reflectors on seismic profiles near the downfan termini of the channels are flatter, more continuous, and less divergent than those in the northern part of the lower fan region (see fig. 11 in Stelting et al., this volume). This seismic character, together with the sandy nature of the sediments recovered at Sites 614 and 615 (Figs. 4 and 5), suggests to some authors the interpretation of "sheet sand" deposition in this region of the fan (Stelting et al., this volume).
Acoustic facies delineated on high-resolution profiles ( 3.5 and $4.5 \mathrm{kHz}$ ) collected from the Mississippi Fan were defined for the upper $\sim 50 \mathrm{~m}$ of the youngest fan lobe. O'Connell and Normark (this volume) constructed regional echo-character maps showing the distribution of these acoustic facies units and also correlated specific reflectors seen on the high-resolution profiles to specific lithologic boundaries in the cores. Varying degrees of correlation exist between these reflectors and the lithologic boundaries recovered in the upper $50 \mathrm{~m}$ of the drillholes. Correlation is best at the two lower fan sites (614 and 615), where grain size variations are greatest; correlation is fair to poor at the middle fan sites, where grain size and bedding thickness variations are subtle (Fig. 5). These results indicate that distinct lithologic boundaries can be correlated with reflectors on highresolution seismic profiles, although not all lithologic boundaries give rise to reflectors.

\section{Sedimentologic Studies}

\section{Composition of Mississippi Fan Sediments}

In addition to the site chapters, several chapters in this volume discuss the mineralogy of the Mississippi Fan sediments drilled during Leg 96 (Brooks et al., this volume; Ishizuka, Kawahata, et al., this volume; Pickering and Stow, this volume; Stow et al., this volume; Thayer 

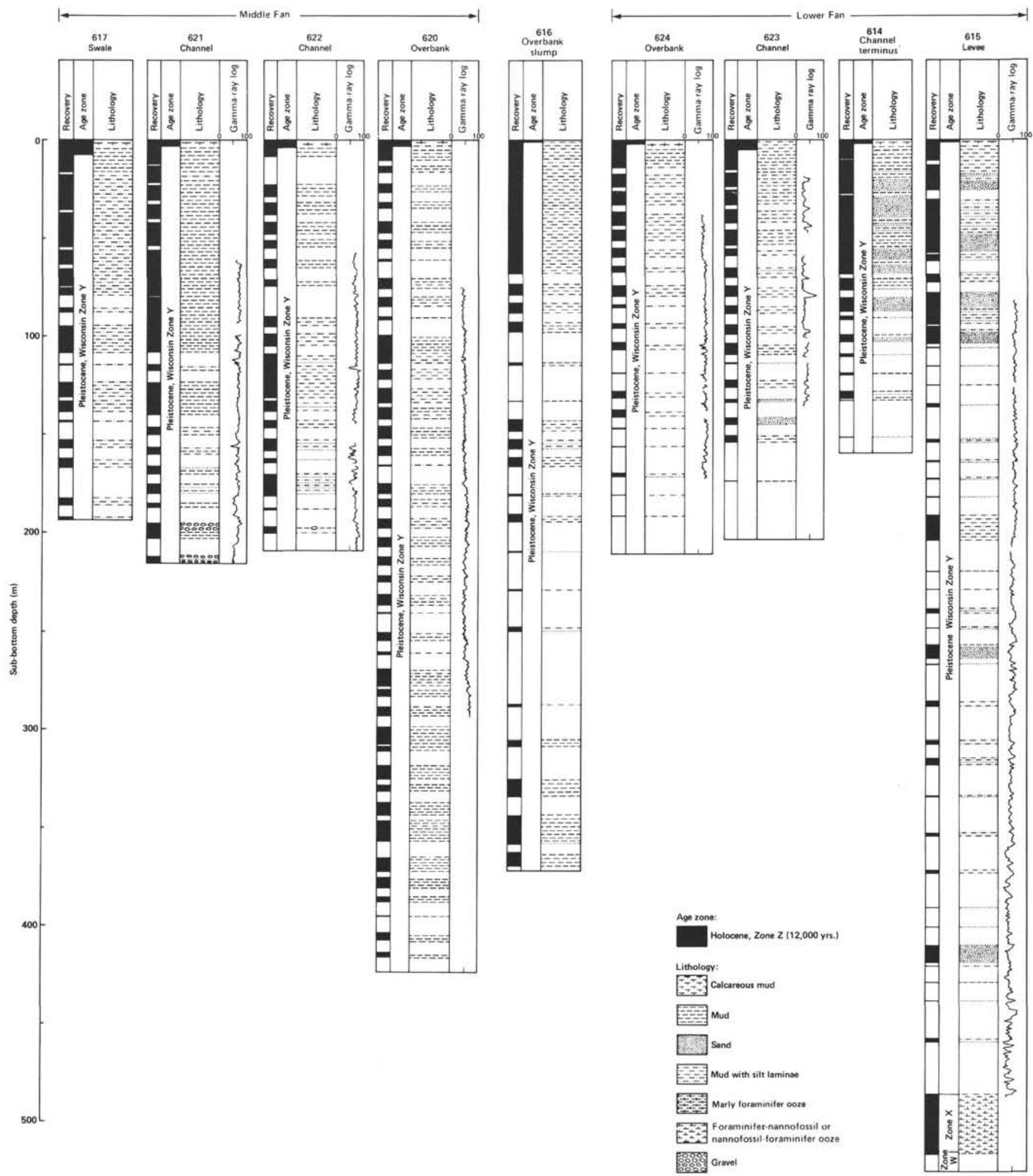

Figure 4. Age, core recovery, general lithology, and gamma-ray data for sites drilled on the Mississippi Fan during DSDP Leg 96. Note especially poor core recovery below approximately $100 \mathrm{~m}$ sub-bottom depth at all drillsites. From Bouma et al. (1984).

et al., this volume). These studies include both petrographic and X-ray diffraction analyses.

\section{Clay Mineralogy}

Clay mineralogy data, based on X-ray diffraction analyses, are presented by Ishizuka, Kawahata, et al. (this volume), Pickering and Stow (this volume), and Thayer et al. (this volume). Results from all three studies are compatible. The dominant clay mineral is smectite (30$50 \%$ ), with subordinate amounts of kaolinite (10-20\%), chlorite (10-20\%), and illite (5-15\%). Pickering and Stow (this volume) also report quartz, feldspars, calcite (with 


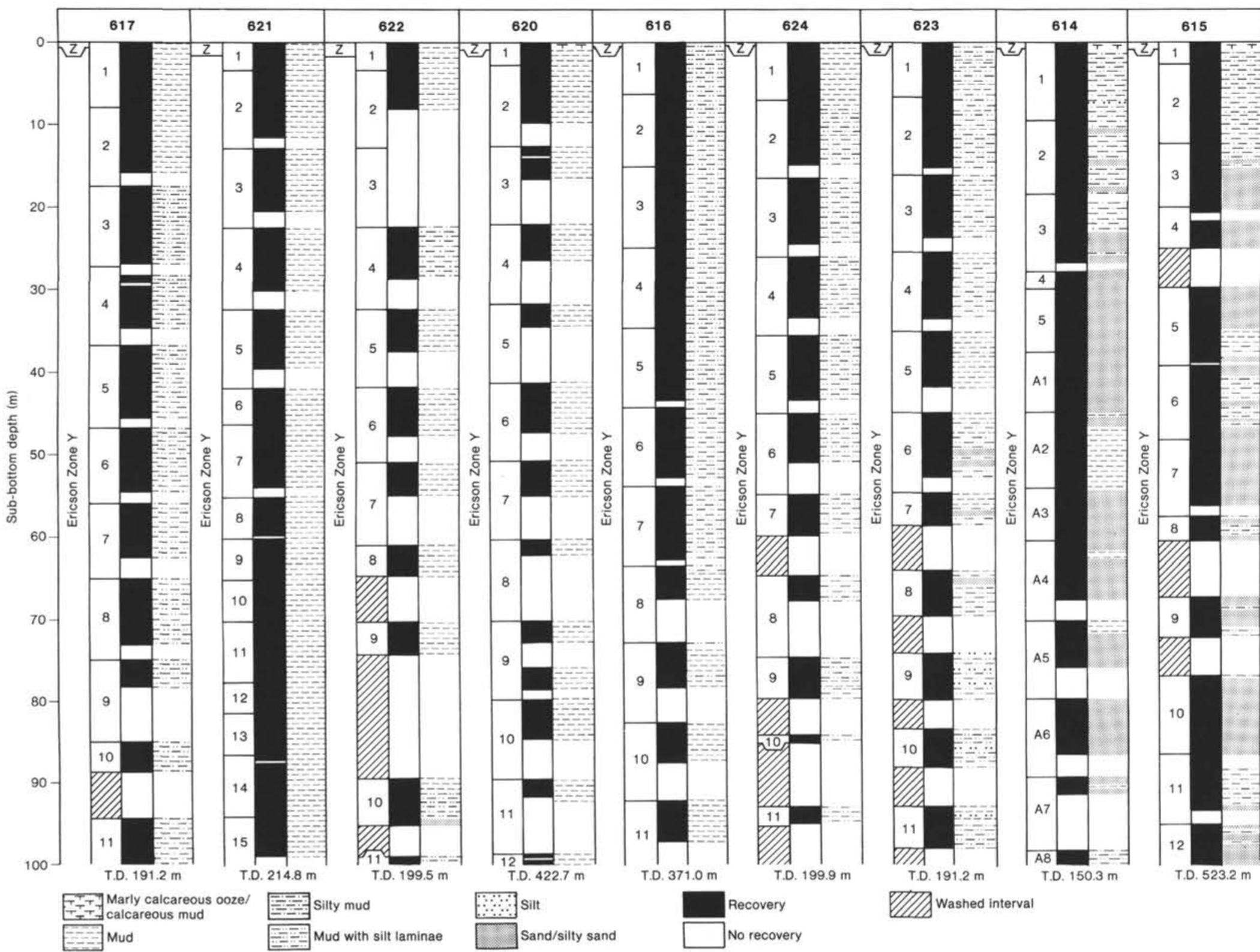

Figure 5. Age, core number and recovery, and lithology of the uppermost $100 \mathrm{~m}$ drilled at the Mississippi Fan sites. Because good core recovery was restricted to the uppermost $100 \mathrm{~m}$ (compare with core recovery data shown in Fig. 4), these sections proved most beneficial in distinguishing the sedimentary facies described in the site chapters (this volume) and Stow et al. (this volume). 
rare aragonite), and dolomite in the clay-sized fraction. Smectite percentages decrease irregularly downhole at several of the sites (especially at Sites 615 and 620, where the deepest holes were drilled), matched by corresponding increases in illite, chlorite, and kaolinite. The smectite content is particularly low within the calcareous ooze deposited during Ericson Zone X (Ericson and Wollin, 1968) near the base of Site 615 (Site 615 chapter, this volume; Fig. 4). The thicker sand and silt sequences, typically found in the lower fan sites (615 and 623), have relatively more quartz and feldspar, a generally higher chlorite-to-kaolinite ratio, and a smaller overall abundance of clay-sized material than middle fan Sites 620 and 621 (Pickering and Stow, this volume).

The clay mineralogy is similar at all the Mississippi Fan sites, suggesting that the source of sediments for the fan did not change during the late Pleistocene. The clay mineralogy is similar in composition to that of the clay found on the modern Mississippi River delta front and upper continental slope, and to the clay being transported and deposited by the modern Mississippi River (Thayer et al., this volume).

\section{Silt and Sand Mineralogy and Grain Shape}

Silt and sand mineralogy data are presented by Stow et al. (this volume), Thayer et al. (this volume), and Mazzullo (this volume). Mazzullo (this volume) also discusses grain shape of detrital quartz sand grains.

The sand beds recovered at the Mississippi Fan sites are uniformly terrigenous and contain minor detrital matrix and reworked biogenic carbonate, along with variable amounts of woody organic debris. These sands range from very fine to very coarse grained, with most being fine to very fine grained, and are moderately to well sorted. They are feldspathic litharenites, sublitharenites, or subarkoses according to Folk's (1980) classification. Quartz is the dominant mineral (55-90\%, mostly strained monocrystalline), with lesser amounts of feldspars (5$20 \%$ ), rock fragments (5-35\%, mostly sedimentary), and accessory detrital minerals (micas, dolomite, glauconite, heavy minerals, woody fragments, and biogenic debris), and authigenic material (dolomite, pyrite, clays, trace gypsum, and calcite). The heavy mineral suite commonly includes amphiboles, pyroxenes, epidote, zircon, tourmaline, and opaque grains. The small biogenic fraction is composed of foraminifers, shallow-water shell debris, and lignitic material. The matrix material is terrigenous mud with subordinate amounts of silt-sized carbonate (reworked skeletal debris); this matrix is most abundant in the fine- and very fine-grained sand.

The silt beds have a similar composition, but contain a greater proportion (10-25\%) of clastic carbonate material of undetermined origin, less quartz, and more common authigenic components. The medium and coarse silts contain up to $20 \%$ woody organic debris.

General similarity between Mississippi Fan and Mississippi River sands suggests to Thayer et al. (this volume) that the fan sands were derived primarily from a Mississippi River source. However, based on studies of the grain shape of detrital quartz sand grains and finegrained sand mineralogy, Mazzullo (this volume) con- cludes that the Mississippi Fan sands are a mixture of Eastern Gulf and Mississippi Province sands, both of which have distinctive mineralogical and quartz grain shape characteristics. This indicates that the fan received sediment both from the Mississippi River system and from the rivers of the southeastern United States during the Pleistocene, both probably transported to deep water via the Mississippi Canyon conduit. Mazzullo documents a significantly smaller contribution of Eastern Gulf Province sand to the sediment section drilled at Sites 621,616 , and 624 than at Sites 623 and 615; based on quartz-grain shape data, more than half of the sands recovered at the latter two sites were derived from the Eastern Gulf Province. While Mazzullo's conclusions appear to be at variance with those of Thayer et al., this discrepancy can be at least partially explained by the fact that Thayer et al. (this volume) use a less restrictive definition of Mississippi-Fan-sand quartz content than either Mazzullo (this volume) or Russell (1937).

\section{Gravel and Pebbly Mud Mineralogy}

Gravels and pebbly muds, concentrated at the base of channel Sites 621 and 622, grade upward into sands containing thin mud interbeds (Fig. 4). The gravel at the base of Site 621 probably is clast supported; Site 622 contains pebble-sized clasts in a poorly sorted silty clay matrix (Site 621 and 622 chapters, this volume). The clasts are up to $3 \mathrm{~cm}$ long, rounded and subrounded, near spherical, often faceted, and poorly sorted. They are composed primarily of chert and polycrystalline quartz, with minor metamorphic, sedimentary, and igneous rock fragments (Thayer et al., this volume). Composition of the fan gravels is similar to that of Pleistocene upland gravels examined from south-central Louisiana (Coleman, pers. commun., 1985). The probable source for this gravel is from deposits buried on the continental shelf near the head of Mississippi Canyon, indicating a minimum transport distance of over $220 \mathrm{~km}$ (Bouma and Coleman, 1984).

\section{Carbonate Ooze Mineralogy}

Brooks et al. (this volume) analyzed the composition of the 29-m carbonate recovered at the base of Site 615 (485.2-514.95 $\mathrm{m}$ below seafloor). They conclude that the interval from 499.4 to $513.7 \mathrm{~m}$ sub-bottom is a single massive carbonate gravity flow (Fig. 4), deposited during Ericson Zone X (late Wisconsin interglacial; Ericson and Wollin, 1968). This gravity flow is sandwiched between two pelagic/hemipelagic calcareous ooze intervals. Brooks et al. suggest that the deposit probably originated as a debris flow and evolved into a high-density turbidity current. It is similar to the well-documented examples of mass-transport sequences in both modern (Crevello and Schlager, 1980) and ancient carbonate settings (Cook and Enos, 1977; Cook and Mullins, 1983; Mutti et al., 1984).

By comparing Site 615 data with compositional data from piston cores collected on the Florida shelf, slope, and adjacent abyssal plain (which contain similar shallow-water carbonate clasts) and seismic correlations, they interpret the West Florida continental slope and outer shelf 
to be the potential provenance area. However, data available from the Yucatan slope are too limited to eliminate that area as an alternative provenance. The presence of this carbonate unit at Site 615 indicates that, although the construction of the Mississippi Fan is certainly dominated by terrigenous input from the Mississippi River and ancestral equivalents, periodic input from adjacent carbonate depocenters also occurred.

\section{Sedimentary Structures of Mississippi Fan Sediments}

Sedimentary structures were described during macroscopic observation of the Mississippi Fan cores on board ship (see site chapters, this volume), and in shore-based thin-section and radiographic analyses. A wide variety of primary and secondary structures were observed in thin sections (see Cremer and Stow, this volume, for a detailed discussion). These structures are best developed in the muds and thinner silts and sands, because most of the thicker sands were extensively deformed by drilling and therefore appear homogeneous. Most of these structures, and their common occurrence in regular vertical successions over 5 - to 100 -cm intervals, can be interpreted in terms of standard sequences for fine-grained turbidites.

Additional information on sedimentary structures in Mississippi Fan sediments is presented in the X-ray radiography study of Coleman, Bouma, et al. (this volume). One hundred and eight thin sediment slabs were evaluated by the X-ray radiography technique. Normally graded parallel laminae and thin beds, ranging in thickness from less than $1 \mathrm{~mm}$ to several centimeters, is the most common small-scale sedimentary structure seen in these slabs. These layers grade from either sand or silt at the base to very fine clay at the top; concentrations of foraminifers may occur at the top of the fine clay. Microcross stratification, thin distorted layers, and microfracturing are rather common. Bioturbation is rare.

\section{Gamma-Ray Well Log Characteristics}

Core recovery at the sites drilled on the Mississippi Fan was generally high $(70-100 \%)$ in the upper $80-90 \mathrm{~m}$, but much lower below that depth (site chapters, this volume; Figs. 4 and 5). In addition, sands greater than 20$25 \mathrm{~cm}$ in thickness were commonly not recovered or were highly disturbed. Because of this poor and selective core recovery, well logs were collected at seven of the Mississippi Fan drillsites to provide information through the unrecovered intervals. Unprocessed well log traces from each of these sites are given in the Introduction, Objectives, and Principal Results chapter (this volume).

The gamma-ray well log traces at six of the Mississippi Fan sites were processed to provide data on grain size trends, bedding thickness, and lithologies of the missing intervals (Coleman, Constans, et al., this volume). Based on correlation with coring results, the processed log responses are divided into three categories: (1) values $>70$ API, indicating structureless "clean" sands; (2) values of 20-70 API, indicating siltier, thin-bedded sediments; and, (3) values $<20 \mathrm{API}$, indicating extremely thin laminated silts and clays or thick-bedded clays. These categories are loosely tied to grain size standards and are named "sand," "silt," and "clay," respectively.
Results from the Coleman, Constans, et al. study indicate that the middle fan channel sites (621 and 622) and the lower fan channel site (623) contain the highest percentage of gamma-ray-calculated "sand," with Site 623 having the highest percentage of the three. Site 623 also contains the highest percentage of gamma-ray-calculated "silt" and the least "clay." Site 620 consists of "silt" with only minor "sand" and "clay." The lower fan overbank site (624) has the highest percentage of "clay" and almost no "sand." The lower fan distal site (615) contains less than $10 \%$ calculated "sand," but is very high in "silt."

\section{Mississippi Fan Lithologic Facies and Depositional Environments}

Leg 96 scientists used the sediments recovered on the Mississippi Fan to (1) define informal lithologic facies, based on lithology, sedimentary structures, composition, and texture parameters (site chapters, this volume; Stow et al., this volume); and (2) characterize the various depositional environments established from side-scan sonar and seismic studies (Coleman, Bouma, et al., this volume).

\section{Lithologic Facies Designations}

Stow et al. (this volume) recognize eight informal lithologic facies in the Mississippi Fan sediments. Gradations exist between these facies, and all occur locally intermixed within disturbed intervals in the cores. Calcareous biogenic facies are of minor volumetric importance compared to the dominant terrigenous facies. Most of the terrigenous facies result from deposition by masstransport flows or other resedimentation processes, as evidenced by the high sedimentation rates, absence of biogenic components and bioturbation, and abundance of primary sedimentary structures indicative of deposition from turbidity currents, debris flows, or sediment slides. These eight lithologic facies may be described as follows:

(1) Ooze and muddy ooze, recovered at the base of Site 615 (Brooks et al., this volume; Site 615 chapter, this volume) and as a thin unit at the top of most of the drillsites. This facies is principally homogeneous or massive, with the exception of the overall normal grading observed at Site 615 .

(2) Calcareous mud, also recovered at the base of Site 615 and tops of most of the drillsites. This facies is transitional with the ooze and muddy ooze facies.

(3) Clay and mud, visually structureless or with rare thin silt laminae or distinct color banding. Sediments of this facies are the finest grained terrigenous material recovered, and occur most commonly in the upper portions of the middle-fan channel sites (621 and 622) and in the "distal" overbank site (620). This facies can be subdivided into sparsely laminated muds and homogenous muds, approximately equivalent to the mud intervals in the silt-laminated mud facies (Cremer and Stow, this volume).

(4) Silty mud and muddy silt, poorly sorted, and forming units that range from about $5 \mathrm{~cm}$ to more than $1 \mathrm{~m}$ in thickness. Sediments of this facies are normally graded, ranging from relatively clean silt to silty mud. They 
are either massive or show regular bedding emphasized by darker laminae. This facies occurs at all the sites, but is slightly more common in the lower fan.

(5) Silt-laminated mud, occurring over intervals of a few centimeters to a few tens of meters in thickness, containing 5-50\% silt laminae and thin silt beds, and exhibiting a large variety of sedimentary structures. Individual silt layers range from thin laminae to beds about $10 \mathrm{~cm}$ thick. Muds are laminated, color banded, or structureless. This facies is the most common facies recovered on the Mississippi Fan, especially at middle-fan overbank and lower fan channel-levee drillsites.

(6) Silt and sand, well-sorted, either graded or massive, and ranging in bed thickness from less than $10 \mathrm{~cm}$ to over $10 \mathrm{~m}$. These sediments contain only poorly developed structures, mostly crude planar lamination. This facies is most common at lower fan Sites 614 and 615.

(7) Muddy gravel and pebbly mud, poorly sorted, and apparently structureless. This facies occurs as minor intervals at the two middle-fan channel sites (621 and 622).

(8) Gravel, apparently clast supported, recovered only at the base of Site 621 in the channel thalweg.

\section{Depositional Environments}

Coleman, Bouma, et al. (this volume) use sedimentologic results from the Leg 96 drillsites to characterize the following five depositional environments on the Mississippi Fan:

(1) Middle-fan channel environment, drilled at Sites 621 and 622 , which shows a fining-upward channel-fill sequence commencing with a basal-lag pebbly gravel (clast-supported at Site 621) that grades upward into massive quartz-rich sand and is capped by fine-grained silt and clay containing thick graded laminae (passive channel fill). The gravel and sand are principally structureless.

(2) Middle-fan overbank environment, drilled at Sites 617 and 620 . The sections drilled at these sites consist primarily of fine-grained silt and clay with only minor amounts of very fine sand. The silt and clay are thinly bedded, graded, and contain ubiquitous, locally distorted structures and small-scale convolute laminations.

(3) Slump-marginal fan environment, drilled at Site 616 , which contains intervals of steeply dipping and structurally contorted clay with thin silt stringers and only minor localized sand. Based on the variable dips observed in these intervals, the shipboard scientists interpret these steeply dipping sediments as a series of smaller slides rather than one massive failure (Site 616 chapter, this volume).

(4) Lower fan channel-overbank environment, drilled at Sites 623 and 624, consisting of alternating channelfill deposits (fining-upward sand and silt units) and overbank sediments (crudely coarsening-upward fine sand, silt, and clay).

(5) Lower fan channel-mouth environment, drilled at Sites 614 and 615 , consisting of medium- to fine-grained, massive, poorly sorted "sheet sands" that contain thin, laminated, graded silt and clay beds. These sites contain the highest percentage of sand and coarse silt recovered on the Mississippi Fan.

\section{DISCUSSION}

Rather than attempt an evaluation of the Leg 96 drilling results by using the extensive list of objectives given in the Introduction, Objectives, and Principal Results chapter (this volume), we comment only on the more significant sedimentologic and stratigraphic findings. The major stratigraphic objective-to establish a time-stratigraphic framework by determining the age and lithologic character of prominent seismic reflectors used to define fan lobes-was achieved at Site 615. Seismic Horizons " 20 " and " 30 " were both peneterated. Horizon " 20 " marks the base of the most recent fan lobe. Core recovery in the depth interval around this reflector was poor and information on the well logs was not particularly informative, so the lithologic nature of the reflector is not defined. The more prominent seismic Horizon " 30 ," however, clearly corresponds to the contrast between terrigenous fan sediments and the calcareous ooze section cored near the bottom of Site 615. This calcareous unit, deposited during the Ericson Zone X, confirms that the youngest fan lobe is late Wisconsin in age and was deposited at a sediment accumulation rate in excess of $6 \mathrm{~m} /$ 1000 yr. Correlation of Horizon " 30 " across the fan allows estimation of sediment accumulation rates at other drill sites (Wetzel and Kohl, this volume).

In comparing sedimentologic results from drilling on the Mississippi Fan with other turbidite systems, especially ancient settings, three critical parameters are involved: (1) the nature of the coarse-grained sediment, (2) the lack of well-defined vertical sequences defined by cored intervals, and (3) the apparent importance of debris flows and slides. We expected that coring on Leg 96 would, at last, allow correlation of a modern turbidite section of more than 10 or $15 \mathrm{~m}$ length with the widely applied facies scheme for ancient turbidites developed by Mutti and Ricci Lucchi (1972). Many of their sedimentary facies distinctions relate to the sandier components of a turbidite section and are based in large part on the grain size changes, internal sedimentary structure, bed thickness, and sand/shale ratios of the sediment in addition to lateral facies changes. Representative samples of the sandy sections from the Mississippi Fan could not be obtained, and many cores of sand units (especially those exceeding $2 \mathrm{~m}$ in thickness) show a high degree of disturbance. Consequently, there are few cored sand beds or sections that allow direct comparison with the Mutti-Ricci Lucchi facies.

Division of the sedimentary sections drilled at the Mississippi Fan sites into sedimentary vertical sequences, as has been routinely done for ancient rocks, is also greatly hampered by the lack of recovery in addition to the severe disruption of sand intervals (Fig. 4). Proposed vertical-sequence divisions are discussed in the site chapters (this volume), Stow et al. (this volume), Coleman, Bouma, et al. (this volume), Wetzel et al. (this volume), and Pickering et al. (1986). The variety of the sequences proposed in these papers, together with the lack of adequate core recovery below $100 \mathrm{~m}$ at most sites, demonstrate the need for the reader to apply such interpretations cautiously, either to other modern fans or to ancient equivalents. For example, many of the vertical sequences proposed 
for ancient turbidites are on the order of meters to a few tens of meters. On Leg 96, the suggested sequences are basically an order of magnitude greater and are based, in many cases, on sections with limited sample recovery.

The drilling results did show that submarine-slide and gravity-flow deposits form an important part of the total sediment volume, at least during the late Wisconsin. Much of the surface of the recent fan lobe is covered by slide and/or slump deposits first noted on $3.5-\mathrm{kHz}$ records by Walker and Massingill (1970) and cored at Site 616. Such large turbidite/debris-flow deposits are common in ancient turbidite basins in small seas (Cook et al., 1972; Cook, 1983; Mutti et al., 1984), and might also be volumetrically significant in the older fan lobes of the Mississippi Fan.

Debris flow(s?) and/or turbidity currents from the Walker and Massingill or other "slumps" appear to have altered the fine-scale morphology in the middle and lower fan. Both deep-towed side-scan and high-resolution reflection profiles, analyzed in detail after the cruise, show a very complex pattern of acoustic characteristics that are suggestive of local erosion and/or partial infilling by some event(s) that have moved across the fan unaffected by the existing channel system (O'Connell, 1986). The varying proportions of sediment derived from the Eastern Gulf Province that exist even between sites that are relatively close (Sites 623 and 624) suggest that gravityflow processes from the margins of the Gulf of Mexico might be a common source of sediment for the fan and that transport from the marginal sources may be relatively oblivious to the existing channel pattern, especially where channel relief is only a few tens of meters. Alternatively, Eastern Gulf Province material may have been either transported by longshore transport to the Mississippi Canyon area where it became mixed with the main sediment supply, or moved downslope in smaller gullies and transported to the west by the Coriolis effect.

The results of drilling at Sites $614,615,623$, and 624 and the emerging pattern of channel remnants that include filled, unfilled, and buried examples (O'Connell, 1986) all suggest that the lower fan sites are on one large or several smaller depositional lobes with ephemeral distributary channels. The most recent compilation of channel occurrences indicates that the channels adjacent to these four lower fan sites do not presently connect to the main channel of the middle fan (Fig. 2). This lobe and the leveed valley at the middle fan sites were both abandoned and have been partly filled or buried by muddy sediments. During the Holocene, even the supply of terrigenous mud was largely cut off, resulting in the hemipelagic ooze at the surface. As the details of the channel pattern are worked out from new GLORIA data acquired after the Leg 96 cruise, the drilling results will become more useful for studying the depositional processes of muddy turbidity currents that are depositing in an area of fine-scale morphology inherited from a more active period (i.e., the time of sand deposition).

\section{REFERENCES}

Addy, S. K., and Buffler, R. T., 1984. Seismic stratigraphy of shelf and slope, northeastern Gulf of Mexico. Am. Assoc. Pet. Geol. Bull., 68:1782-1789.
Barnes, N. E., and Normark, W. R., 1985. Diagnostic parameters for comparing modern submarine fans and ancient turbidite systems. In Bouma, A. H., Normark, W. R., and Barnes, N. E. (Eds.), Submarine Fans and Related Turbidite Systems: New York (Springer-Verlag), pp. 13-14, wall map.

Bouma, A. H., and Coleman, J. M., 1984. Seismic stratigraphy and sedimentology of Leg 96 drilling on the Mississippi Fan. Characteristics of Gulf Basin Deep-Water Sediments and their Exploration Potential: Austin, Texas (Fifth Annual Research Conference, Gulf Coast Section), Soc. Econ. Paleontol. Mineral. Found., pp. 11-22.

Bouma, A. H., Coleman, J. M., and DSDP Leg 96 Shipboard Scientists, 1985. Mississippi Fan: Leg 96 Program and principal results. In Bouma, A. H., Normark, W. R., and Barnes, N. E. (Eds.), Submarine Fans and Related Turbidite Systems: New York (Springer-Verlag), pp. 247-252.

Bouma, A. H., Coleman, J. M., Meyer, A. W., Brooks, J., Bryant, W., et al., 1984. Challenger drills Mississippi Fan. Geotimes, July 1984:15-18.

Bouma, A. H., Normark, W. R., and Barnes, N. E., 1985. COMFAN: Needs and initial results. In Bouma, A. H., Normark, W. R., and Barnes, N. E. (Eds.), Submarine Fans and Related Turbidite Systems: New York (Springer-Verlag), pp. 7-11.

Bouma, A. H., Stelting, C. E., and Coleman, J. M., 1985. Mississippi Fan, Gulf of Mexico. In Bouma, A. H., Normark, W. R., and Barnes, N. E. (Eds.), Submarine Fans and Related Turbidite Systems: New York (Springer-Verlag), pp. 143-150.

Cook, H. E., 1983. Ancient carbonate platform margins, slopes, and basins. Soc. Econ. Paleont. Mineral. Short Course 12(5):1-189.

Cook, H. E., and Enos, P. (Eds.), 1977. Deep-water carbonate environments. Soc. Econ. Paleontol. Mineral. Spec. Publ., 25.

Cook, H. E., McDaniel, P. N., Mountjoy, E. W., and Pray, L. C., 1972. Allochthonous carbonate debris flows at Devonian bank ('reef') margins, Alberta, Canada. Bull. Can. Pet. Geol., 20:439497.

Cook, H. E., and Mullins, H. T., 1983. Basin margin. In Scholle, P. A., Bebout, D. G., and Moore, C. H. (Eds.), Carbonate Depositional Environments. Am. Assoc. Pet. Geol. Mem., 33:539-617.

Crevello, P. D., and Schlager, W., 1980. Carbonate debris sheets and turbidites, Exuma Sound, Bahamas. J. Sediment. Petrol., 50:11211147.

Curray, J. R., Emmel, F. J., Moore, D. G., and Raitt, R. W., 1982. Structure, tectonics, and geological history of the northeastern Indian Ocean. In Nairn, A. E. M., and Stehli, G. (Eds.), The Ocean Basins and Margins (Vol. 6): New York (Plenum Pub. Corp.), 399-450.

Damuth, J. E., Kowsmann, R. O., Flood, R. D., Belderson, R. H., and Gorini, M. A., 1983. Age relationships of distributary channels on Amazon Deep-Sea Fan: implications for fan growth pattern. Geology, 11:470-473.

Droz, L., and Bellaiche, G., 1985. Rhone deep-sea fan: morphostructure and growth pattern. Am. Assoc. Pet. Geol. Bull., 69:460-479.

Ericson, D. B., and Wollin, G., 1968. Pleistocene climates and chronology in deep-sea sediments. Science, 162:1227-1234.

Ewing, M., Worzel, J. L., et al., 1969. Init. Repts. DSDP, 1: Washington (U.S. Govt. Printing Office).

Folk, R. L., 1980. Petrology of Sedimentary Rocks: Austin (Hemphill Publ. Co.).

Garrison, L. E., Kenyon, N. H., and Bouma, A. H., 1982. Channel systems and lobe construction in the Mississippi Fan. Geo-Mar. Lett., 2:31-39.

Kastens, K. A., and Shor, A. N., 1985. Depositional processes of a meandering channel on Mississippi Fan. Am. Assoc. Pet. Geol, Bull., 69:190-202.

Martin, R. G., 1978. Geologic framework of northern and eastern continental margins, Gulf of Mexico. In Bouma, A. H., Moore, G. T., and Coleman, J. M. (Eds.), Beyond the Shelf Break. Am. Assoc. Pet. Geol., Marine Geology Comm. Short Course:A1A28.

Moore, G. T., Starke, G. W., Bonham, L.C., and Woodbury, H. O., 1978. Mississippi Fan-Gulf of Mexico-physiography, stratigraphy, and sedimentational patterns. In Bouma, A. H., Moore, G. T., and Coleman, J. M. (Eds.), Framework, Facies, and Oil-Trapping Characteristics of the Upper Continental Margin. Am. Assoc. Pet. Geol., Stud. Geol., 7:155-191. 
Moore, G. T., Woodbury, H. O., Worzel, J. L., Watkins, J. S., and Starke, G. W., 1979. Investigation of Mississippi Fan, Gulf of Mexico. Am Assoc. Pet. Geol. Mem., 29:383-402.

Mutti, E., and Ricci Lucchi, F., 1972. Le torbiditi dell' Appennino settentrionale-introduzione all'analisi si facies. Soc. Geol. Ital. Mem., 11:161-199.

Mutti, E., Ricci Lucchi, F., Seguret, M., and Zanzucchi, G., 1984. Seismoturbidites: a new group of resedimented deposits. Mar. Geol., 55:103-116.

Normark, W. R., 1978. Fan valleys, channels, and depositional lobes on modern submarine fans: characteristics for recognition of sandy turbidite environments. Am. Assoc. Pet. Geol. Bull., 62:912-931.

Normark, W. R., Barnes, N. E., and Bouma, A. H., 1985. Comments and new directions for deep-sea fan research. In Bouma, A. H., Normark, W. R., and Barnes, N. E. (Eds.), Submarine Fans and Related Turbidite Systems: New York (Springer-Verlag), pp. 341343.

O'Connell, S., 1986. Anatomy of modern submarine depositional and distributary systems [Ph.D. thesis]. Lamont-Doherty Geological Observatory, Columbia University, New York.

Pickering, K., Coleman, J., Cremer, M., Droz, L., Kohl, B., et al., 1986. A high sinuousity, laterally migrating submarine fan channel-levee-overbank: results from DSDP Leg 96 on the Mississippi Fan, Gulf of Mexico. Mar. Pet. Geol., 3:3-18.

Russell, R. D., 1937. Mineral composition of Mississippi River sands. Geol. Soc. Am. Bull., 48:1307-1348.
Schlager, W., Buffler, R. T., and Scientific Party of DSDP Leg 77, 1984. Deep Sea Drilling Project, Leg 77, southeastern Gulf of Mexico. Geol. Soc. Am. Bull., 95:226-236.

Shaub, E. J., Buffler, R. T., and Parsons, J. G., 1984. Seismic stratigraphic framework of deep central Gulf of Mexico Basin. Am. Assoc. Pet. Geol. Bull., 68:1790-1802.

Stelting, C. E., and DSDP Leg 96 Sedimentologists, 1985. Migratory characteristics of mid-fan meander belt, Mississippi Fan. In Bouma, A. H., Normark, W. R., and Barnes, N. E. (Eds.), Submarine Fans and Related Turbidite Systems: New York (Springer-Verlag), pp. 283-290.

Stow, D. A. V., Howell, D. G., and Nelson, C. H., 1985. Sedimentary, tectonic, and sea level controls. In Bouma, A. H., Normark, W. R., and Barnes, N. E., (Eds.), Submarine Fans and Related Turbidite Systems: New York (Springer-Verlag), pp. 15-22.

Stuart, C. J., and Caughey, C. A., 1976. Form and composition of the Mississippi Fan. Gulf Coast Assoc. Geol. Soc. Trans., 26:333-343.

Walker, J. R., and Massingill, 1970. Slump features on the Mississippi Fan, northeastern Gulf of Mexico. Geol. Soc. Am. Bull., 81:31013108 .

Worzel, J. L., Bryant, W., et al., 1973. Init. Repts. DSDP, 10: Washington (U.S. Govt. Printing Office).

Date of Initial Receipt: 23 September 1985

Date of Acceptance: 5 February 1986 